\title{
Lack of Malyl-CoA Lyase in a Mutant of Pseudomonas AM1
}

\author{
By A. R. SALEM*, A. J. HACKING AND J. R. QUAYLE \\ Department of Microbiology, University of Sheffield, Sheffield S ro $2 T N$
}

(Received 10 December 1973)

\begin{abstract}
Pseudomonas AMI contains malyl-CoA lyase (Salem, Hacking \& Quayle, I973a) which catalyses the reaction:

$$
\text { 4-Malyl-CoA } \rightleftharpoons \text { acetyl-CoA + glyoxylate }
$$
\end{abstract}

This reaction may serve to regenerate the glyoxylate necessary for operation of the serine pathway during growth of the organism on $\mathrm{C}_{1}$ compounds. The evidence for this comes from isotopic experiments with the intact organism indicating that the glyoxylate arises from symmetrical cleavage of $\mathrm{a} \mathrm{C}_{4}$ compound derived from succinate (Salem, Large \& Quayle, 1972), and from the fact that the specific activity of malyl-CoA lyase is several-fold higher in Pseudomonas AMI when grown on $\mathrm{C}_{1}$ compounds than when grown on multicarbon substrates (Salem et al. 1973a).

Additional support for the suggested physiological role of the enzyme has now been obtained through a study of mutants of the organism. A consequence of the loss of malylCoA lyase from Pseudomonas AMI should be inability to grow on $\mathrm{C}_{1}$ compounds unless supplemented with substrate quantities of glyoxylate or a precursor such as glycollate. Several mutants with this nutritional phenotype have already been isolated (Dunstan, Anthony \& Drabble, I972 b; Salem \& Quayle, I971; Salem, Wagner, Hacking \& Quayle, $1973 b$ ). While screening such mutants for malyl-CoA lyase we found that the enzyme is almost absent in mutant PCT57, isolated by Dunstan et al. (1972b), and that revertants of this mutant which have regained the ability to grow on $\mathrm{C}_{1}$ compounds possess the enzyme at levels 30 - to 60-fold higher than in the parent mutant.

\section{METHODS}

Growth of the organism. Mutant PCT57 was kindly provided by Dr C. Anthony, Department of Physiology and Biochemistry, University of Southampton, SO9 $5 \mathrm{NH}$. It was grown at $30{ }^{\circ} \mathrm{C}$ under the same conditions as those described for Pseudomonas AM I (Heptinstall \& Quayle, 1970) using carbon sources at $50 \mathrm{~mm}$ concentration except for ethanol $(0.5 \%)$, methanol $(0.5 \%)$, pyruvate $(30 \mathrm{~mm})$ and glyoxylate (I0 $\mathrm{mM})$. For some experiments, succinate-grown PCT 57 was harvested by centrifugation, resuspended overnight in methanolgrowth medium at $30^{\circ} \mathrm{C}$ and re-harvested. Such organisms are referred to as 'methanolinduced'. Streptomycin-resistant $\left(\mathrm{Sm}^{\mathrm{r}}\right)$ variants of mutant PCT57 were isolated by subculturing on succinate agar plates in the presence of I mg streptomycin/ml (Dunstan, Anthony \& Drabble, 1972a). Revertants of $\mathrm{Sm}^{\mathrm{r}}$ mutants to growth on methanol were obtained by plating approximately $10^{7} \mathrm{Sm}^{\mathrm{r}}$ organisms on methanol-agar medium containing streptomycin and prepared with a surface disc of filter paper saturated with $\mathrm{N}$ methyl- $\mathrm{N}^{\prime}$-nitro- $N$-nitrosoguanidine $(4 \mathrm{mg} / \mathrm{ml})$. Several $\mathrm{Sm}^{\mathrm{r}}$ revertant colonies appeared outside the zone of growth inhibition. Four of these colonies were picked and streaked for

* Present address: Experimental Chemotherapy Division, May \& Baker Ltd, Dagenham, Essex, RM 107 XS. 
Table I. Specific activity of malyl-CoA lyase in extracts of wild type Pseudomonas AMI and derived mutants

\begin{tabular}{|c|c|c|}
\hline Organism & Growth substrate & $\begin{array}{l}\text { Malyl-CoA lyase } \\
\text { activity } \\
\text { ( } \mu \text { mol } / \mathrm{min} / \mathrm{mg} \\
\text { protein })\end{array}$ \\
\hline \multirow{2}{*}{$\begin{array}{l}\text { Pseudomonas AMI } \\
\text { (wild type) }\end{array}$} & Succinate & $0.30 *$ \\
\hline & Methylamine & $1 \cdot 45^{*}$ \\
\hline \multirow[t]{2}{*}{ РCT57 } & Succinate & 0.005 \\
\hline & $\begin{array}{l}\text { Succinate-grown, } \\
\text { methanol induced }\end{array}$ & 0.005 \\
\hline PCT $57-R_{1}$ & Methylamine & $0.2 \mathrm{I}$ \\
\hline PCT $57-R_{2}$ & Methylamine & 0.30 \\
\hline PCT $57-R_{3}$ & Methylamine & 0.15 \\
\hline PCT $57-R_{4}$ & Methylamine & 0.20 \\
\hline
\end{tabular}

single colony isolation (PCT57- $R_{1},-R_{2},-R_{3}$ and $-R_{4}$ respectively), then grown up in liquid culture on methylamine + streptomycin ( $\mathrm{mg} / \mathrm{ml}$ ) and extracted for assay of malyl-CoA lyase.

Preparation of bacteria-free extracts. Extracts were prepared by ultrasonication (Heptinstall \& Quayle, 1970), and after centrifugation at $20000 \mathrm{~g}$ for $30 \mathrm{~min}$ the supernatant was used for enzyme assay.

Enzyme and protein assays. The activity of malyl-CoA lyase was measured as described by Salem et al. (1973a) and is expressed as $\mu \mathrm{mol}$ of glyoxylate produced $/ \mathrm{min} / \mathrm{mg}$ protein. Protein was determined by the Folin-Ciocalteu method (Lowry, Rosebrough, Farr \& Randall, I95I) using bovine serum albumin as standard.

\section{RESULTS AND DISCUSSION}

Mutant PCT57 grew on the following compounds: succinate, pyruvate, 3-hydroxybutyrate, ethanol and oxalate, but not on methylamine or methanol unless supplemented with glycollate. These properties correspond with those reported by Dunstan et al. (1972 b) but unlike these authors, we did not observe appreciable growth in methanol+glyoxylate media. The reason for this discrepancy is not known; however, the revertants to growth on methanol were found to grow slowly on methanol $+5 \mathrm{~mm}$-glyoxylate but not at all on methanol+ Io mM-glyoxylate, and in this respect they were much more sensitive to growth inhibition by glyoxylate than was the wild-type organism. Also, PCT57 itself was more sensitive to inhibition by glyoxylate during growth on succinate than was the wild-type organism. Such sensitivity to growth inhibition by glyoxylate might also explain the inability of glyoxylate to substitute for glycollate as a growth supplement for mutant PCT57.

Mutant PCT57 is able to oxidize methanol and contains the following enzymes of the serine pathway: serine-glyoxylate aminotransferase, hydroxypyruvate reductase (EC. I . I . I . 29) and glycerate kinase (EC. 2.7 . I .3 I) (Dunstan et al. 1972 b). However, extracts of succinate-grown PCT57 contained very low activities of malyl-CoA lyase (Table I) corresponding to less than $2 \%$ of the value in the succinate-grown wild-type organism. Overnight incubation of the mutant in methanol growth medium did not result in higher activity of the lyase, showing that the mutant was unable to synthesize the enzyme even in the presence of methanol as inducer. Four independently isolated revertants from PCT57 which were now 
able to grow on $\mathrm{C}_{1}$ compounds possessed malyl-CoA lyase with specific activities 30- to 60 -fold higher than that in the parent mutant (Table I). Introduction of streptomycin resistance into the parent mutant and revertants guarded against contamination of the cultures with wild-type Pseudomonas AMI.

The growth rates of the revertants on methylamine were comparable with that of the wild-type organism even though they contained malyl-CoA lyase at only Io to $20 \%$ of the activity of the methylamine-grown wild-type organism. This is not inconsistent with the postulation of a key role for malyl-CoA lyase in growth on $\mathrm{C}_{1}$ compounds, since even at specific activities of 0.15 to $0.30 \mu \mathrm{mol} / \mathrm{min} / \mathrm{mg}$ protein the enzyme is more active than several established enzymes of the serine pathway in wild-type Pseudomonas AMI and thus it may not impose a significant restriction on the growth rate of the revertants.

We acknowledge financial support from the Science Research Council under grant No. $\mathrm{B} / \mathrm{RG} / 27 \mathrm{II} 8$.

\section{REFERENCES}

Dunstan, P. M., ANThony, C. \& Drabble, W. T. (1972a). Microbial metabolism of $C_{1}$ and $C_{2}$ compounds. The involvement of glycollate in the metabolism of ethanol and of acetate by Pseudomonas AM I. Biochemical Journal 128, 99-106.

Dunstan, P. M., Anthony, C. \& Drabble, W. T. $(1972 b)$. Microbial metabolism of $C_{1}$ and $C_{2}$ compounds. The role of glyoxylate, glycollate and acetate in the growth of Pseudomonas AMI on ethanol and on $\mathrm{C}_{1}$ compounds. Biochemical Journal 128, 107-II5.

HePtinstall, J. \& Quayle, J. R. (1970). Pathways leading to and from serine during growth of Pseudomonas AMI on $C_{1}$ compounds and succinate. Biochemical Journal II7, 563-572.

Lowry, O. H., Rosebrough, N. J., Farr, A. L. \& Randall, R. J. (I95I). Protein measurement with the Folin phenol reagent. Journal of Biological Chemistry 193, 265-275.

Salem, A. R., Hacking, A. J. \& QuAYLe, J. R. (I973a). Cleavage of malyl-coenzyme A into acetyl-coenzyme A and glyoxylate by Pseudomonas AMI and other $\mathrm{C}_{1}$-unit-utilizing bacteria. Biochemical Journal 136, 89-96.

SAlem, A. R. \& QUAYLE, J. R. (I97I). Mutants of Pseudomonas Ami that require glycollate or glyoxylate for growth on methanol or ethanol. Biochemical Journal 124, 74P.

Salem, A. R., Large, P. J. \& QuAYle, J. R. (1972). Glycine formation during growth of Pseudomonas ami on methanol and succinate. Biochemical Journal 128, I 203-I2 I I.

Salem, A. R., Wagner, C., HAcking, A. J. \& QuaYle, J. R. (I973 $b$ ). The metabolism of lactate and pyruvate by Pseudomonas AMI. Journal of General Microbiology 76, 375-388. 